\title{
BRANDING TRADITIONAL AND NATURAL PRODUCTS BY PROVIDING TOURIST EXPERIENCE: WHAT ARE THE EFFECTS
}

\author{
Ivana First Komen \\ Sanja Stamenić Oštrić
}

https://doi.org/10.20867/tosee.05.29

\begin{abstract}
The mission of this research is to analyze how small producers of natural and traditional products can strengthen their position in the market and bring positive change to themselves and their stakeholders by establishing a brand and making it stronger through storytelling, organic certification and providing tourist experience. The study was approached inductively, by applying in-depth multiple source analysis on an identified exemplar case. The results show that creating a brand story and getting and presenting organic label are important factors for the market success, but yield limited results without consumers having the opportunity to experience the brand and its story. Producers of natural and traditional products are adviced to think of ways of how to provide consumer experience and how to get consumers in touch with their products, i.e. how to turn a non touristic business into a touristic one. This will have the strongest effect on their own sales, but will also benefit the other stakeholders the most.
\end{abstract}

Keywords industrial tourism, tourist experience, storytelling, traditional and natural products

\section{INTRODUCTION}

Producers who use natural and traditional resources are usually small entrepreneurs, and according to Renton et al. (2016) small entrepreneurs boil down their branding efforts to mere definition of business values. Such modest approach to branding does not bring out the potential that branding offers and results in suboptimal market performance or even closure of traditional and natural products' producers. That further, unfortunately, leads entrepreneurs to believe that managing natural and traditional resources in a sustainable way cannot bring economic value which in turn poses a threat of devastation of such resources. Not only is this problematic from a cultural and environmental point of view, but also from the economic. That is, traditional industries (Hafeez et al., 2016) and autochthonous products (Oliva and Paliaga, 2012) contribute to creation of a strong and recognisable destination brand for domestic and foreign tourists. Hence, lack of strong brands of natural and traditional products erodes touristic image of a country being traditional and rich in cultural heritage and makes it less appealing to tourist expenditures.

Still there are some producers of natural and traditional products who develop strong brands, charge premium prices, achieve market success, and often being rooted in small communities, contribute to the local tourist experience and community as a whole. The assumption of this research is that success for such producers lies in creating strong 
ToSEE - Tourism in Southern and Eastern Europe, Vol. 5, pp. 291-306, 2019

I. First Komen, S. Stamenić Oštrić: BRANDING TRADITIONAL AND NATURAL PRODUCTS BY ...

brands which offer value to customers by offering a brand story (cf. Solja et al., 2018), an organic certification (Schouteten et al., 2019) and tourist experience creation (cf. Mitchell and Orwig, 2002). These three factors are identified in literature as some of the important market success factors, but their relative importance and potential cause and effect relationships need to be established.

It is the aim of this research to conduct an in depth analysis on an identified exemplar case in order to discover paths to success and effects that such success has on various stakeholder. This study is considered an initial qualitative phase of a long term research which will contribute to gathering new insights to help small producers of natural and traditional products strengthen their position in the market through establishing their own brand and linking brand story to nature, and tradition. Furthermore, it is the contribution of this research that it extends understanding of the role that traditional and natural product producers may have on overall destination and community development by entering tourist industry and developing a tourist brand.

\section{LITERATURE REVIEW}

This section presents short literature review on the three identified factors of success in creating strong brand of products based on natural and traditional resources. They are getting involved in experiential tourism, storytelling, and organic certification. To keep clarity, each factor is going to be presented in a separate subchapter.

\subsection{The importance of getting involved in experiential industrial tourism}

Pine and Gilmore (1998) define experience economy as the fourth stage of the economic development and presented four types of experiences: entertainment, education, aesthetics, and escapism. Already Pine and Gilmore noticed that experience economy is not convenient and recommended for the entertainment industry only; but still today many industries do not approach their product as an experience, but rather as a product or a service.

Pine and Gilmore's experience economy constructs have been tested and employed in different tourism-related studies by several scholars. For example, Loureiro (2014) found that the more experience is offered, the stronger pleasant arousal and memory of the rural tourism. According to Taheri et al. (2018), contemporary tourists seek a unique and authentic experience to get to know local people and their way of living. These tourists look for authentic experience by attending local festivals (Chung et al., 2018), getting involved in the local customs (Lee, Chao, Lin, 2018), and life in general (Prince, 2017, Locaric et al. 2018), visiting heritage sites and ethnographic museums (Taheri et al. 2018), eating local foods (Choe and Kim, 2018; Mykletun, Gyimothy, 2010) and lodging by the locals (Wiles, Crawford, 2017).

Furthermore, such tourists love to get involved in the so called industrial tourism which includes manufacturing plant tours, company museums and company visitor centres (Mitchel and Orwig, 2002). Industrial tourism originally referred to visiting factories of the closed enterprises, but later, operating businesses got involved in this kind of tourism 
ToSEE - Tourism in Southern and Eastern Europe, Vol. 5, pp. 291-306, 2019

I. First Komen, S. Stamenić Oštrić: BRANDING TRADITIONAL AND NATURAL PRODUCTS BY ...

as they realised it helps them show tourists company spirit and provide them entertainment and knowledge about the manufacturing process by participating in handson activities. That way tourists get interested and bonded to a given brand (Mitchell \& Orwig, 2002, Chow et al., 2017; Chien, Wu, and Huang, 2018). Therefore, Sidali et al. (2015) building on the experience economy theory, stress how rural entrepreneurs and policy makers can market food specialties and rural regions (such as Parmigiano Reggiano) to the post-modern consumer by opening food museums, in which a romantic view of agriculture prevails.

Opening up production sites for tourism and in general developing tourism in an area is not only beneficial for the tourist entrepreneur, but generates change in terms of economic growth and community development (Aquino, Luck, Schanzel, 2018; Amalu et al., 2018). For that reason, involvement of producers of natural and traditional products in tourism becomes an important driver of local development and brings multiplying positive effects.

\subsection{The importance of storytelling}

The importance of a story for a brand has been studied for a long time, but one of the early significant papers is by Boje (1995) in which he described Walt Disney as a storrytelling organisation an hence an interesting and successful organisation. Since then storytelling has been studied in marketing research and is cosidered as an effective tool to develop trustworthy brands and strong consumer brand relationships. Solja et al. (2018) for example, found that even a short brand story included on FMCG packaging has a positive impact on consumers' affective, attitudinal, product value, and behavioral intention responses to the brand. Similarly, results of Fengera et al. (2015) suggest that consumers who were not interested for the new food product became interested when storytelling was introduced, while those of Lundqvist et al. (2013), suggest that consumers exposed to storytelling described the brand in more positive terms and were willing to pay more. Finally, Ryu et al. (2019) found that a brand story that has a historical connection, a clear plot and is narrated in the first person enhances image of a brand.

When traditional and natural products are involved, storytelling is considered not only important as with any other brand, but also an option easy to apply. That is, a story with a historic conotation is by definition tied to a traditional product and thus gets easily absorbed by the consumers. Hence, storytelling in the context of traditional and natural products seems to be a very recommended tool.

\subsection{The importance of organic certification}

As consumers become more interested in healthy lifestlyes, producers tend to opt for the ecolables and bio certificates in order to attract more consumers. Bauer et al. (2013) show that the use of an organic label affects consumers' perceptions of global, local, and private brands with regard to consumers' purchase intentions and willingness to pay a price premium, but private brands (op. a. being the least strong) seem to profit from that the most. Accordingly, it is to be expected that brand of small natural and traditional product producers who are also usually not very strong will yield significant benefit from that as 
ToSEE - Tourism in Southern and Eastern Europe, Vol. 5, pp. 291-306, 2019

I. First Komen, S. Stamenić Oštrić: BRANDING TRADITIONAL AND NATURAL PRODUCTS BY ...

well. Schouteten et al. (2019) showed that providing an organic label on varoius food categories leads to a higher overall liking and willingness to pay both in the experimental context but also in the real life context. Drexler et al. (2018), however, by combining eye-tracking and interviews confirmed that ecolabels can attract the attention of consumers, but ecolabels do not guarantee increased sales, as $50 \%$ of consumers buy organic products only in exceptional cases.

\section{METHODOLOGY}

This chapter is divided in three subchapters. The first one introduces a methodological approach (a case study method) and elaborates on how validity and reliability are tackled within such a scientific approach. The second subchapter presents the case study and the third explains the data gathering protocol.

\subsection{Methodological Approach, Validity and Reliability}

Having in mind that a scope of this research, i.e. discovering the mechanisms of company success and the effects it has on the community, is content wise very comprehensive, methodology wise it needs to be very exhaustive and accurate to provide basis for sensemaking. Furthermore, as this is the initial stage of the research, the research focuses on one exemplar case, but with an in-depth approach. According to Langley (1998) such approach to sensemaking is referred to as narrative sense making strategy. To provide reliable and valid research findings from a single case study, guidelines by Gibber, Ruigrok, and Wicki (2008) are followed. To ensure internal validity, research framework derives from the literature and different theoretical approaches are proposed: storytelling (Solja et al., 2018), organic certification (Schouteten et al., 2019) and tourist experience creation (Mitchell and Orwig, 2002). To ensure construct validity, data triangulation was used (interviews, archival data, and web site content analysis), transcripts were sent for authorisation to the informants, circumstances of data collection and analysis were explained. External validity is the most critical for a single case analysis. Nevertheless, some measures ensure certain level of external validity, i.e. there is a detailed explanation for why this case was chosen as an exemplar and what is the context of the case analysed. Finally, reliability is achieved by giving a detailed explanation of the research protocol, by giving organizational real name and by keeping database of all interview transcripts, content analysis coding schemes, photographs etc.

\subsection{The Case Study, the Context and Generalisability of the Findings}

The case is saline Solana Nin. It is an exemplar case for several reasons. First of all, it produces salt, which is a commodity, but it manages to sell it for about 10 times higher price than competitors (e.g. in its own web shop (Solana Nin, 2018), salt is sold for about $40 \mathrm{HRK}^{1} / \mathrm{kg}$, with some basic and bulk packaged products being cheaper and most ingredient-wise or package-wise enhanced products being sold for much higher prices). Secondly, their production is heavily relying on traditional hand-made procedures of sea salt collection, the product is highly natural and possesses a bio certificate. Thirdly,

\footnotetext{
${ }^{1} 1 \mathrm{HRK}=0,13$ EUR (https://www.xe.com/currencyconverter/convert/?Amount=1\&From=HRK\&To=EUR)
} 
ToSEE - Tourism in Southern and Eastern Europe, Vol. 5, pp. 291-306, 2019

I. First Komen, S. Stamenić Oštrić: BRANDING TRADITIONAL AND NATURAL PRODUCTS BY ...

Solana reside in a small community of the town of Nin and is expected to be important for the community.

Nin is a small costal town in south Croatia, $20 \mathrm{~km}$ from Zadar with only 2744 inhabitants (DZS, 2011). According to HGK (2018), there are 57 (4 small and 53 micro) companies registered in Nin, with 192 employees, revenues of 53.7 mil HRK and profit of $2.8 \mathrm{mil}$ $\mathrm{kn}$. Solana Nin in the same time has 27 employees (second biggest employer), revenues of 9.1 mil HRK (the highest revenues), and profit of 1,1 mil HRK (the highest profit). Furthermore, there are about 1.560 .000 tourists in the county in 2017 (HTZ, 2018). According to the Town of Nin strategy of development (Grad Nin, 2016), salt collection and production is the oldest town's industry and is today represented by Solana Nin. Furthermore, according to the same document Town of Nin touristic strategy of development, identifies five touristic products of the town among which industrial tourism based on Solana Nin. Finally, in the document Solana Nin is identified as one of the town's strengths and as a potential leader of the capital investment projects related to priority area: all year round tourist program. All this data show the importance of Solana for the community.

When it comes to comparing Solana Nin to the industry in Croatia, according to HGK (2018), there are 7 companies registered for salt excavation $(\mathrm{NKD}=\mathrm{B} 0893)$ in Croatia. Analysis of web pages of those companies reveals that only three have their own excavation pools in Croatia and are comparable from the point of view of this research, while the others focus on salt production of imported salt. According to the results of HGK (2018) all of the 7 companies together have revenues of 135.9 mil HRK, but the three with Croatian saline generate revenues of 62.3 mil HRK. According to Fininfo (2019), the other two companies' operating profit reveals financial problems.

\subsection{Data gathering protocol}

Firstly, to capture the idea of the case, an in-depth interviews with the owners as well as analysis of Solana's web site were conducted. Secondly, to understand Solana's market success, some of the shops displaying Solana's products were observed and publicly available financial data were compared to the industry and local community peers. The first two steps provided grounds to believe that the case is interesting in terms of having applied an interesting strategic marketing approach and in terms of having achieved market success.

From there on, the following steps were very focused and structured in order to determine what led to Solana Nin's success and what are the consequences for its stakeholders. So, as a third step, local community's web sites were analysed. As the fourth step, a field trip to Nin was conducting. Interviews were conducted with the operating manager as well as tourist programme manager of Solana Nin (in the further text: company managers). Furthermore, the interview was also conducted with the major and the director of the tourist board of Nin (in the further text: town officials). Finally, short, unannounced interviews were conducted with several citizens and a tourist agency employee (in further text: community). The fifth step was targeted archival data analysis in search of proofs for what was indicated during the previous stages of the research. 
ToSEE - Tourism in Southern and Eastern Europe, Vol. 5, pp. 291-306, 2019

I. First Komen, S. Stamenić Oštrić: BRANDING TRADITIONAL AND NATURAL PRODUCTS BY ...

\section{RESULTS}

This chapter is comprehensive and quite detailed at points, but as explained in chapter 3 , this is a single case research, so data needs to be compared across several relevant sources and information needs to be explained in detailed. This chapter is organised according to various sources and methods used. The first subchapter presents relevant web sites content analysis; the second subchapter, the analysis of the interview with the owners; the third one, analysis of other interviews; and the fourth one, archival data analysis.

\subsection{Web Sites Content Analysis}

The web site of Solana (Solana Nin, 2018) was analysed to comprehend the main message Solana portrays to its stakeholders. Web site is information reach and presented in a form of a story, clearly indicating that the company is all about the story of salt. On the web site, it is visible that the web site itself, but also packaging and educational tours offered in Solana all serve as a media for company's storytelling. The story in particular stresses several ideas: bring people closer to nature and tradition by producing products that are bio certified, that are produced in a traditional and hand made way at a venue that has been in the same business for 1500 years, since the Roman times, and after so many years is still well preserved which is evidenced by about 200 spices of birds (including some endemic) breeding at its pools. The web site also shows a very wide range of Solana Nin's products. Most of its 130 products displayed on the web site are salt intense and include: flower of salt, table salt, salt with spices, bathing salt. However, there are about $20 \%$ of products in which salt represents only minor portion of ingredients (soaps, bathing gels, toothpastes, cheese, olive oils, chocolates etc.) and about $10 \%$ with no salt at all (salt containers and mills). Such diversification of portfolio especially in the direction of non-salt intense products, is considered a wise strategic move. Firstly, it reduces the risk of natural disasters that threat saline (rainy summers) and enables Solana to grow in revenues beyond what is conditioned by limited amounts of salt collection (3200T on average yearly). Secondly, cooperation with producers who have the same values like Solana Nin, i.e. hand work, respect of tradition and nature, unites such small producers and makes their position in consumer minds, and in the market stronger since they cobrand, promote each other, and use each others' distribution channels. Finally, the web sites shows how important tourism is considered for the company as out of 10 tabs on the home page, 2 are devoted to tourism: House and museum of salt and Tours.

To gain further comprehension of the importance of Solana Nin for the region (apart from the figures presented in section 3.2.), web sites of the tourist board Nin (TZ Nin, 2019), the town of Nin (Grad Nin 2019), the tourist board of the county of Zadar (TZ Zadar county, 2019) and the tourist board of the city of Zadar (TZ Zadar, 2019), were analysed. Nin was chosen as it is the home town of Solana while Zadar as the county capital. While for the town of Nin, Solana represents an important player, at the county level it loses its prominence. Tourist board of Nin mentions Solana very often, concretely within the most important four out of eight tabs: About Nin (Nin today and Awards list), Guide (Calendar of events), Heritage (Salt, The bird world and Museum of salt), and Interesting (Ideas for a perfect day). On the web site of the town of Nin, Solana is mentioned within one out of eight tabs. Concretely, under the tab Nin info (Economy), 
ToSEE - Tourism in Southern and Eastern Europe, Vol. 5, pp. 291-306, 2019

I. First Komen, S. Stamenić Oštrić: BRANDING TRADITIONAL AND NATURAL PRODUCTS BY ...

Solana is the first company to be presented while under the same tab (subtab Tourism) it is presented as the central point of Nin's industrial tourism. On the other hand, on the web site of the tourist board of the Zadar county, Solana is mentioned in two out of four tabs under the Where to go (Destinations) and Discover (Local life) tabs. Finally, on the web site of tourist board of the town of Zadar, Nin in general is mentioned only twice (as an excursion idea) while there is no mention of the Solana Nin during the Nin excursions.

Finally, Trip advisor (2019) has been analysed. Solana Nin is according to 110 tourist reviews ranked no 7 out of 16 things to do when in Nin. It is graded with the average grade 3,5 with the median and mode being 4 . Altogether there were 77 reviews written in English, Italian, German and Serbian (languages understood by the authors) since July 2014 to February 2019 which were content analysed. Almost all analysed reviews $(n=73)$ describe the content of Solana (mentioning the museum and the guided tour and focusing on the souvenir shop and gifts). Most tourist $(n=57)$ take positive or negative judgemental stance on some of the marketing mix elements (mostly price, physical environment, and personnel), and $(n=53)$ evaluate brand image and perceived quality (good quality salt, variety of products, and history), as well as the main consumer benefits of the visit $(n=45)$ (informative and interesting). Finally, many tourists conclude that Solana Nin is worth visiting. Overall, it is the impression that the reviews on the trip advisor are of the tourists who came across the museum as individuals and are trilled by the experience of learning about the traditional production of the autochthonous product and the possibility of buying a souvenir that represents a tradition, but also a highly functional product which due to its nice packaging can serve as a memorabilia or a nice gift.

\subsection{Analysis of interview with the owners}

The main point of interviewing the owners was to understand how they initiated rebranding and achieved market success within few years. Brand owners briefly explained the situation they encountered when they bought Solana Nin in 2009 and outlined the strategy they decided to pursue. "Ten years ago, Solana Nin was selling cheap salt in local supermarkets in Zadar county and to local fisherman companies. There were no souvenirs, nor souvenir shop. Even the pools were dirty and ruined". Solana was opened for the tourist, but with their low interest since brand awareness was very low. Then, new owners decided to rebrand and reposition Solana which included definition of new company values and their instilment to the company through internal branding; new distribution channels; and product innovations. Important elements of building brand identity of Solana Nin were: "beautiful location, nature, traditional and innovative products, people and tourism". Creativity in branding, products (including the whole new product category - tourist products), and packaging was considered important issue, as it resulted in bigger national market share, better distribution coverage, new customers, and loyal customers.

According to the owners, different channels required different products and different value emphasis. For example, to enter DM or Bio\&bio it was necessary to emphasize Bio certificate as these channels are bio exclusive. To enter Lush, hand-made production was the selling point. For supermarkets, kitchen salt is the appropriate product and so on. According to the owner's estimates, Bio salt and kitchen salt is almost exclusively sold 
ToSEE - Tourism in Southern and Eastern Europe, Vol. 5, pp. 291-306, 2019

I. First Komen, S. Stamenić Oštrić: BRANDING TRADITIONAL AND NATURAL PRODUCTS BY ...

to industry buyers and supermarkets, with minimal portions being sold in souvenir shops and in the restaurants. Flower of salt (bio) is sold about $45 \%$ to souvenir shops, $45 \%$ to supermarkets and industrial buyers, while about $10 \%$ to the restaurants. The rest of the products (cosmetics with salt, salt with spices, delicacies with salt and wooden and ceramic souvenirs) are exclusively sold in souvenir shops (souvenir and delicacies shops, duty free shops and Solana's own souvenir shop).

According to the owners, "tourism with 70.000 - 100.000 visitors yearly in Solana is becoming essential for development of this company and currently brings $30 \%$ of the total revenues". Furthermore, extension of new salt products fitted for tourists coming to Solana, also attracted many other souvenir shops and duty free shops throughout Croatia to buy Solana Nin's products. This innovative distribution channel "grows $20 \%$ per year and just a few years ago it was non existent". Hence, the effect of entering tourism for the company is actually even much higher that the $30 \%$ sales revenue within its own souvenir shop. It is not to be neglected that Solana also supports local economy and community as it offers job opportunities.

\subsection{Other interviews analysis}

During all the other interviews, there were two mojors areas of research that the questions were directed towards: the perceived reasons of Solana Nin's market succcess, and the perceived effects of Solana on the stakeholder. For each, several themes were discovered. The resons for the success was the topic that was discussed with the town officials and the company managers, while the effects with town officials, the company managers and the community.

As for the reasons of success, town officials and company managers, agree that the key for success was opening up of the production site for the tourists and creating the experience. Company managers also explain that a small museum\&souvenir shop was opened in 2011 when also guided tours were approached more seriously while in 2016 The House of Salt (i.e. the proper museum) was opened. They further elaborate: "Opening the production site for the visitors provides experience, which then results in visitors purchasing 5-10 products after the tour. This further results in $40 \%$ of total sales being achieved in the Solana's souvenir shop, and not to forget that the profit in that channel is the highest". They further claim that opening of a production site for the tourists also "made the brand stronger which then enabled development of new distribution channels such as souvenir shops and direct export”.

Town officials and company managers, both agree that vital for the success was the story (in this case related to tradition), risk taking (in terms of thinking out of the box and investing in marketing), and creating emotion. There were some other causes of success mentioned like knowledge by the town official and passion by company managers. Also, town officials emphasize that added value is the key, while company managers emphasize innovation and uniqueness in terms of tradition, variety of products, flower of salt and variety of channels. What is particularly interesting is that each distribution channel purchases different type of product and for a different reason. According to company managers: "Tommy supermarket chain is their major wholesale buyer in terms of revenues. They mostly buy table kitchen salt. On the other hand souvenir shops and 
ToSEE - Tourism in Southern and Eastern Europe, Vol. 5, pp. 291-306, 2019

I. First Komen, S. Stamenić Oštrić: BRANDING TRADITIONAL AND NATURAL PRODUCTS BY ...

duty free shops recognised some of our products as an excellent souvenir (not kitchen salt)" but rather delicacies and flower of salt. "DM lists only our bio salts, because they are bio. In Solana's museum we mainly sell flower of salt which brings highest revenues, and scented bath salts and salt with spices, which are sold in highest quantities."

As for the effects that Solana's success has on the other stakeholders, several stakeholders were mentioned in an open type question: town, citizens, tourists, tourist industry. All the interviewees agree that Solana's change of the strategy introduced since 2009 brought positive change to the town. Town officials emphasize that the brand of the city became stronger with the rise of Solana Nin's brand. As they also add, "Solana Nin's products are used as the official gifts to the town's guests and as a symbol of the town at tourist fairs". Furthermore, citizens used to complain that the "landscape of the town would be nicer without Solana claiming that the town does not need an acient and devastated saline, but should rather focus on tourism. However, with the change of the strategy of Solana, cleaning of the pools, and openin Solana for the tourists, citizens realised that Solana actually fosters tourism (and what is more, all year round type of tourism)". Furthermore, town officials and company managers agree that citizens are emotionally connected to Solana as generations have been working in it and they feel proud of its current success. Finally, according to all interviewees, Solana adds value to Nin's tourists. Town officials are specific and mention that "in 2018 there were 155.000 tourist in Nin of which majority visited Solana as it is interesting for tourists seeking to experience the local culture, tourists interested in bird watching or tourists looking for the eco experience".

When interviewees were explicitly asked whether they consider that Solana brings value to other entrepreneurs be it in the tourist industry or wider, the following was revealed. There is no official statistics, nor tracking of the tourist paths, as in how many come to Nin because of Solana, and how many of them visit restaurants and bars or stay overnight in Nin. However, a significant number of them has come to Nin because of Solana and do consume some other Nin's tourist product. Furthermore, although accoring to town's officials for the town's budget Solana is not significant, its influence in the economic sense is not neglectible. It represents "a role model of successful business embeded in touristic trends" to other entrepreneurs in the region, and wider.

\subsection{Archival data analysis}

Archival data was analysed focusing on discovering proofs in numbers for what was discovered during the previous phases of the research.

Table 1. demonstrates several important issues. Firstly, in its own production site (souvenir shop and museum) company achieves as much as $30 \%$ of sales revenues. Furthermore, other souvenir shops and duty free shops, which are indirectly the result of Solana Nin's strategic decision to enter tourism and innovate products to be attractive for tourists, currently bring $11 \%$ of sales revenues and grow at a rate of $56 \%$ in two years with 9 souvenir shops in 2016 and 21 in 2018. Finally, export is now represented by only $3 \%$, but it is mostly also the result of tourism. That is, foreign tourists who visit Solana often initiate sales imports to their own countries. Table 1 also shows that tourism related 
ToSEE - Tourism in Southern and Eastern Europe, Vol. 5, pp. 291-306, 2019 I. First Komen, S. Stamenić Oštrić: BRANDING TRADITIONAL AND NATURAL PRODUCTS BY ...

sales (which is currently $44 \%$ of sales revenues) grows much faster (at a rate of $43 \%$ in 2 years as opposed to $26 \%$ growth rate of non tourist related sales).

Table 1: Sales revenues across distribution channels

\begin{tabular}{|c|c|c|c|c|c|c|c|}
\hline & \multicolumn{2}{|l|}{2016} & \multicolumn{2}{|l|}{2017} & \multicolumn{2}{|l|}{2018} & \multirow[t]{2}{*}{$\begin{array}{l}\text { Growth } \\
\text { 2016-2018 }\end{array}$} \\
\hline & HRK & $\%$ & HRK & $\%$ & HRK & $\%$ & \\
\hline $\begin{array}{l}\text { Solana's } \\
\text { souvenir shop } \\
\text { \& entrance } \\
\text { tickets }\end{array}$ & 2.282 .304 & $30 \%$ & 2.630 .105 & $29 \%$ & 3.121 .979 & $30 \%$ & $37 \%$ \\
\hline $\begin{array}{l}\text { Souvenir shops } \\
\text { \& Duty free }\end{array}$ & 738.780 & $10 \%$ & 945.510 & $11 \%$ & 1.150 .837 & $11 \%$ & $56 \%$ \\
\hline Export & 151.480 & $2 \%$ & 316.885 & $4 \%$ & 266.524 & $3 \%$ & $76 \%$ \\
\hline Industry & 3.283 .907 & $42 \%$ & 3.636 .635 & $41 \%$ & 3.721 .708 & $36 \%$ & $13 \%$ \\
\hline Supermarkets & 1.263 .128 & $16 \%$ & 1.414 .182 & $16 \%$ & 1.998 .434 & $19 \%$ & $58 \%$ \\
\hline Restaurants & 8.156 & $0,1 \%$ & 17.678 & $0,2 \%$ & 21.940 & $0,2 \%$ & $169 \%$ \\
\hline Total & 7.727 .756 & & 8.960 .995 & & 10.281 .422 & & $33 \%$ \\
\hline
\end{tabular}

Source: Solana Nin's internal documents

According to company arhives it is also visible that tourism did not come as a result of mere value adding to products and opening of saline for tourists, but it involved intense personal sallinf effort as well. That is, Solana Nin cooperates with 27 tourist agencies who bring groups (adults or students). Furthermore, to foster subsequent purchases of (foreign) tourists who once visited Solana, webshop (currently in 6 languages) was opened in 2015 and although it reaches small sales amounts, in less than four years it registered 253 Croatian and 189 foreign buyers from 21 countries.

Of the 3.1 mil HRK sold in Solana's souvenir shop, $18 \%$ goes to bio flower of salt, $14 \%$ to entrance tickets to house of salt and saline tours, $13 \%$ to salt with spices, further $13 \%$ to bathing salts, and $10 \%$ to bio salt. About $25 \%$ of sales in Solana Nin's souvenir shop is achieved by sales of products with low content of salt and produced by partners (e.g. soaps, toothpastes, chocolates etc.). This information implies that the decision to diversify its product portfolio beyond logical options and adjust it to tourists was necessary and fruitful. When it comes to how important bio products in tourism context are, it seems they are, since e.g. bio salt brings $10 \%$ of revenues, while kitchen salt which is very similar only $2.5 \%$.

Archival data also shows that the success of Solana Nin has positive effect on several stakeholders. Graph 1 e.g. shows that organised group school visits represet a very significant portion of the visits. According to the impressions books, children do not buy too much in the souvenir shop after their visit as they find products to be too expensive, but are still considered important target group and are still activelly invited to Solana Nin. This shows Solana Nin's commitment to preservation of traditional values and educating children about it. The graph further shows that there are many organised children groups and adult groups coming to Nin because of Solana. It can be assumed 
ToSEE - Tourism in Southern and Eastern Europe, Vol. 5, pp. 291-306, 2019 I. First Komen, S. Stamenić Oštrić: BRANDING TRADITIONAL AND NATURAL PRODUCTS BY ...

that their visit to Nin includes visiting other Nin's sites and consumption outside of Solana as well.

\section{Graph 1: Ticket sales over years}

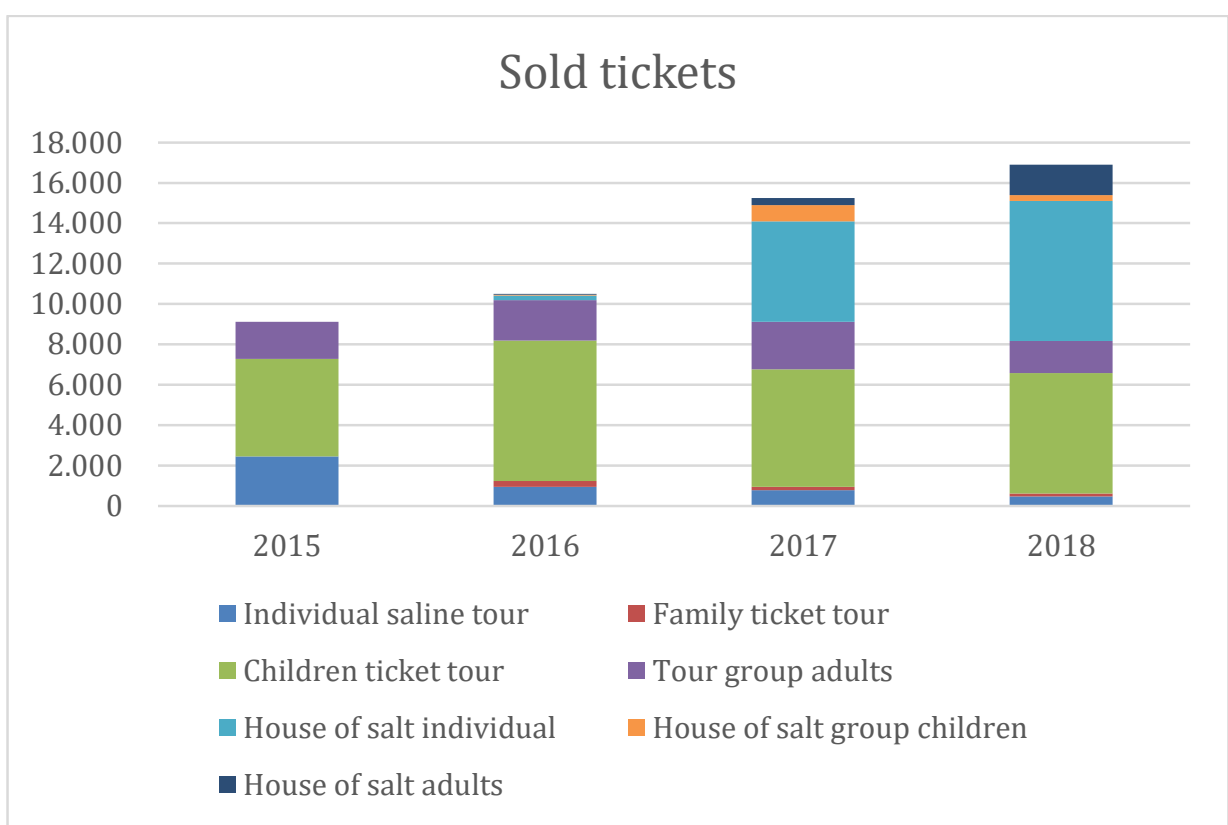

There are about 17.000 tickets sold according to the graph, but it is estimated that there are many more visitors to Solana Nin since during summer every two weeks Open door days are organises with free entrance (and this are the most crowded days in Solana as evidenced by the invoice analysis).

Source: Solana Nin's internal documents

Furthermore, Solana's archival data show that there are about 30 delicacies and souvenir type products that are produced by Solana Nin partners (all representing small natural and traditional producers). These products brought 892.700 HRK in 2018, which is about $10 \%$ of the total company's sales. This numbers demonstrate that success of Solana Nin, brings business growth to other similar producers as well.

\section{DISCUSSION AND MANAGERIAL IMPLICATIONS}

Based on all of the gathered data, it can be concluded that creating a story of a brand is important for the market success of natural and traditional products, but it yields limited results without consumers having the opportunity to experience that story. Furthermore, label organic gives benefits, but in this case it was found it does not play a crucial role. Therefore, it is the conclusion that providing consumers with the opportunity to experience the story is the most important marketing activity for the success of traditional and natural producers. This case portrayed tourist tours and visits as a media for experiencing the brand story, but there may be other similar and alternative options. 
ToSEE - Tourism in Southern and Eastern Europe, Vol. 5, pp. 291-306, 2019

I. First Komen, S. Stamenić Oštrić: BRANDING TRADITIONAL AND NATURAL PRODUCTS BY ...

Table 2 presents the individual effects of the three marketing activities discussed throughout the paper: creating brand story (Solja et al., 2018), organic certification (Schouteten et al., 2019) and providing tourist experience (Mitchel and Orwig, 2002) As the table shows, tourism has the widest scope of effects for the company and its stakeholders. Obviously, it is this of the three marketing activities that is the only one which yields effects for the tourists and tourist industry. It is also the only one which resulted in growth of partner companies (suppliers). The effects it has on the company comes for two reasons. Firstly, a new highly profitable and well controlled channel is opened; and secondly brand equity is increased in terms of three dimensions: awareness, perceived quality and image. That is also in line with previous research (Chow et al., 2017). This two effects then result in higher volume sales and higher revenues for the company. Although the effects are less strong for the local economy and community they are not to be overlooked as the table shows.

Creating story of a brand itself influences brand equity, but not as much as tourism does (only brand image and possibly perceived quality are affected). Creating a story and opening production site for the tourists is mutually reinforcing as a good story is a precondition for the tours to be interesting, tourists happy and so on, but in the same time happy tourists spread positive stories. As Kumar and Gilovich (2015) emphasize, purchasing experience as opposed to purchasing material goods has much stronger effect on storytelling among consumers. Finally, creating a story of a traditional and natural brand must naturally be related to tradition and nature and that very fact means that Solana's decision to create and live story about trdition and nature, contributes to the community as it protects natural and traditional heritage.

Finally, owning a bio certificate proved to be a good way to open up new distribution channel (supermarkets focused on bio food), but this channel is in terms of revenue not even close to the company's own channel (opened due to tourism). Bio certificate also strengthens brand equity (although only brand image and perceived quality as two dimensions of brand equity), which is benefitial for the company but also for non tourist consumers to whom that certificate represents quality assurance. Finally, bio certificate helps in creating brand story and making it authentic, and as was discussed above, authentic story fosters tourism and so on. Finally, having a bio certificate and offering tourism are also mutually reinforcing marketing activities. That is, tourists like museum to be eco-friendly and to educate them to behave so themselves (Han, et al., 2018) and therefore tourists may be seen as agents of change for environmental betterment as McBoyle (1996) noticed in a study on "greening" Scottish malt whisky distilleries. 
ToSEE - Tourism in Southern and Eastern Europe, Vol. 5, pp. 291-306, 2019

Table 2: The individual benefits of the three strategic marketing activities

\begin{tabular}{|c|c|c|c|c|c|c|}
\hline $\begin{array}{l}\text { Strategic } \\
\text { marketing } \\
\text { activities }\end{array}$ & $\begin{array}{l}\text { for the } \\
\text { company }\end{array}$ & $\begin{array}{l}\text { for the } \\
\text { tourists }\end{array}$ & $\begin{array}{l}\text { For the } \\
\text { non tourist } \\
\text { consumers }\end{array}$ & $\begin{array}{l}\text { For the local } \\
\text { tourist } \\
\text { industry }\end{array}$ & $\begin{array}{l}\text { for the local } \\
\text { economy }\end{array}$ & $\begin{array}{l}\text { For the local } \\
\text { community }\end{array}$ \\
\hline \multirow[t]{2}{*}{ Bio certificate } & $\begin{array}{l}\text { Higher } \\
\text { brand } \\
\text { equity: } \\
\text { image and } \\
\text { perceived } \\
\text { quality }\end{array}$ & & $\begin{array}{l}\text { Value } \\
\text { added by } \\
\text { quality } \\
\text { assurance }\end{array}$ & & & \\
\hline & $\begin{array}{l}\text { New } \\
\text { channels }\end{array}$ & & & & & \\
\hline \multirow[t]{4}{*}{$\begin{array}{l}\text { Creating } \\
\text { tourist } \\
\text { experience }\end{array}$} & $\begin{array}{l}\text { Higher } \\
\text { brand } \\
\text { equity } \\
\text { (awareness, } \\
\text { image and } \\
\text { perceived } \\
\text { quality) }\end{array}$ & $\begin{array}{l}\text { Value } \\
\text { added by } \\
\text { providing } \\
\text { experience }\end{array}$ & & $\begin{array}{l}\text { More } \\
\text { tourists }\end{array}$ & $\begin{array}{l}\text { Higher } \\
\text { employment }\end{array}$ & \\
\hline & $\begin{array}{l}\text { Important } \\
\text { new } \\
\text { channel }\end{array}$ & $\begin{array}{l}\text { Special gift } \\
\text { products }\end{array}$ & & Longer stays & $\begin{array}{l}\text { Partner } \\
\text { companies } \\
\text { growth }\end{array}$ & \\
\hline & $\begin{array}{l}\text { Much } \\
\text { higher } \\
\text { sales } \\
\text { volumes }\end{array}$ & & & $\begin{array}{l}\text { Higher } \\
\text { tourist } \\
\text { consumption }\end{array}$ & & \\
\hline & $\begin{array}{l}\text { Higher } \\
\text { income }\end{array}$ & & & & & \\
\hline \multirow[t]{3}{*}{$\begin{array}{l}\text { Story of a } \\
\text { brand: } \\
\text { natural and } \\
\text { traditional }\end{array}$} & $\begin{array}{l}\text { Higher } \\
\text { brand } \\
\text { equity: } \\
\text { image (and } \\
\text { perceived } \\
\text { quality) }\end{array}$ & & & & & $\begin{array}{l}\text { Industrial } \\
\text { heritage } \\
\text { preservation }\end{array}$ \\
\hline & & & & & & $\begin{array}{l}\text { Natural } \\
\text { heritage } \\
\text { preservation }\end{array}$ \\
\hline & & & & & & $\begin{array}{l}\text { Local } \\
\text { community } \\
\text { satisfaction }\end{array}$ \\
\hline
\end{tabular}

So, based on all of the above elaborated, producers of natural and traditional products are first of all adviced to think of the ways how to provide consumer experience and how to get consumers in touch with production of their products or its raw materials. This in other word means that they should think of how to turn a non touristic business into a touristic one. They are further adviced to create a brand story emphasizing for the consumers important benefits (be it natural, organic, hand made or similar) which together with getting in touch with the production makes brands authentic and interesting. The third piece of advice for the producers of naturala and traditional products is to think of how to enrich products and product portfolio as once the consumer is in the shop, he is willing to purchase more products would there be more products displayed. 
ToSEE - Tourism in Southern and Eastern Europe, Vol. 5, pp. 291-306, 2019

I. First Komen, S. Stamenić Oštrić: BRANDING TRADITIONAL AND NATURAL PRODUCTS BY ...

\section{LIMITATIONS AND DIRECTIONS FOR FUTURE RESEARCH}

The aim of this research was to discover how small producers of natural and traditional products can strengthen their position in the market through establishing their own brand and linking brand story to nature, tradition and organic label and how can their success effect various stakeholder. The study approached this matter from an inductive point of view trying to understand the complex mechanisms of change. For the reason of applying rigorous multiple source in-depth analysis focused on one case only. Such approach inherently has its limitations and the findings need to be validated with a deductive approach in the future research.

To strengthen internal validity within the given case, more details can be gathered regarding the consumer paths, and discover the full results tourism brought to the company and its stakeholders. That is, conducting quantitative research among consumers who have been purchasing in the web shop or have initiated wholesale exports, should reveal to which extent their purchases have been motivated by a prior production site visit and how much they contribute to purchases in supermarket or souvenir shop channels. Furthermore, by conducting the quantitative research among the future tourists to Solana, it can be discovered how they found Solana, whether they tried its products previously, whether Solana was the reason to visit Nin and how much those that came to Nin for the Solana, consume outside of Solana once in Nin. Moreover, one of the assumption of this research was that producers of natural and traditional products who have a strong brand contribute to country's image as rich in cultural heritage, hence enriching tourists' experience and satisfaction. Therefore, a comparative research among tourists who visited Solana and those who have not but otherwise both had similar touristic experience would also reveal what is the full impact of Solana Nin's decision to enter tourism.

To test external validity, more similar examplar cases should be discovered and in-depth analysed. Although it would eventually also be important to discovered unsuccessful cases and compare them to successful once, it is believed that this research is still in the phase of discovering success factors of the successful cases.

\section{ACKNOWLEDGEMENTS}

This work has been supported in part by the University of Rijeka under the project number: uniri-drustv-18-163.

\section{REFERENCES}

Amalu, T.E., Otop, O.O., Duluora, E.I., Omeje, V.U., and Emeana, S.K (2018), "Socio-economic impacts of ecotourism attractions in Enugu state, Nigeria”, Geojournal, Vol. 83, No. 6, pp. 1257-1269.

Aquino, R.S., Luck, M., and Schanzel, H.A. (2018), "A conceptual framework of tourism social entrepreneurship for sustainable community development", Journal of Hospitality and Tourism Management, Vol. 37, pp. 23-32.

Bauer, H.H., Heinrich, D. Schafer, D.B. (2013), "The effects of organic labels on global, local, and private brands More hype than substance?", Journal of Business Research, Vol. 66, No. 8, pp. 1035-1043. DOI: 10.1016/j.jbusres.2011.12.028 
ToSEE - Tourism in Southern and Eastern Europe, Vol. 5, pp. 291-306, 2019 I. First Komen, S. Stamenić Oštrić: BRANDING TRADITIONAL AND NATURAL PRODUCTS BY ...

Boje D.M. (1995), "Stories of the storytelling organization: a postmodern analysis of Disney as "TamaraLand"', Academy of Management Journal, Vol. 38, No. 4, pp. 997-1035, DOI: 10.2307/256618

Chien, S.H., Wu, J.J. and Huang, C.Y. (2018), "We made, we trust: Coproduction and image congruence in the food-tourism factories", Asia Pacific Management Review, Vol. 23, No. 4, pp. 310-317 DOI: 10.1016/j.apmrv.2018.01.002

Choe, J.Y., and Kim, S. (2018), "Effects of tourists' local food consumption value on attitude, food destination image, and behavioral intention", International Journal of Hospitality Management, Vol. 71, pp. 110

Chow, H.W., Ling, G.J., Yen, I.Y. and Hwang, K.P. (2017), "Building brand equity through industrial tourism", Asia Pacific Management Review, Vol. 22, No. 2, pp. 70-79 DOI: 10.1016/j.apmrv.2016.09.001

Chung, J.Y., Kim, J.S., Lee, C.K. and Kim, M.J. (2018), "Slow-food-seeking behaviour, authentic experience, and perceived slow value of a slow-life festival", Current Issues in Tourism, Vol. 21, No. 2, pp 123-127.

Drexler, D., Fiala, J., Havlíčková, A., Potůčková, A. and Souček, M. (2018), “The Effect of Organic Food Labels on Consumer Attention”, Journal of Food Products Marketing, Vol. 24, No. 4, pp. 441-455. DOI: $10.1080 / 10454446.2017 .1311815$

DZS (2011), Popis stanovništva, kućanstava i stanova 2011, Viewed $20^{\text {th }}$ February 2019 , https://www.dzs.hr/hrv/censuses/census2011/results/htm/H01_01_03/h01_01_03 zup13.html

Fengera, M.H.J., Aschemann-Witzela, J., Hansen, F., Grunerta, K.G. (2015), "Delicious words - Assessing the Impact of Short Storytelling Messages on Consumer Preferences for Variations of a New Processed Meat Product", Food Quality and Preference, Vol. 41, pp. 237-244 DOI: $10.1016 /$ j.foodqual.2014.11.016

FinInfo (2019) viewed 1st March 2019, www.fininfo.hr

Gibbert M., Ruigrok W. and Wicki, B. (2008), "Research Notes and Commentaries: What Passes as a Rigorous Case Study?", Strategic Management Journal, Vol. 29, No. 13, pp. 1465-1474 DOI: $10.1002 / \mathrm{smj} .722$

Grad Nin (2019), viewed, $2^{\text {nd }}$ January 2019, www.grad-nin.hr

Grad Nin (2016), Strategija razvoja grada Nina 2016. - 2020., viewed $19^{\text {th }}$ February 2019, http://www.gradnin.hr/wp-content/uploads/2017/01/Strategija-razvoja-Grada-Nina-2016.-2020..pdf

Hafeez, K., Foroudi, P., Keith, D., Nguyen, B. and Parahoo, S. K. (2016) "The role of place branding and image in the development of sectoral clusters: the case of Dubai", Journal of Brand Management, Vol. 23, No. 4, pp. 383-402

Han, H., Olya H.G.T., Cho, S.B. and Kim, W. (2018), "Understanding museum vacationers' eco-friendly decision-making process: strengthening the VBN framework", Journal of Sustainable Tourism Vol. 26, No. 6, pp. 855-872

HGK (2018), Digitalna komora, viewed 20 February 2019, www.digitalnakomora.hr

HTZ (2018), Turizam u brojkama 2017., Ministarstvo turizma Republike Hrvatske, viewed $28^{\text {th }}$ December 2018, https://www.htz.hr/sites/default/files/2018 08/HTZ\%20TUB\%20HR_\%202017\%20FINAL.pdf

Kumar, A. and Gilovich, T. (2015), "Some 'Thing' to Talk About? Differential Story Utility from Experiential and Material Purchases", Personality and Social Psychology Bulletin, 41(10), pp. 1320-1331.

Langley, A. (1998), "Strategies for theorizing from process data", Academy of Management Review, Vol. 24 No. 4, pp. 691-710

Lee, T.H., Chao, W.H. and Lin, H.Y. (2018), "Cultural inheritance of Hakka cuisine: A perspective from tourists' experiences", Journal of Destination Marketing \& Management, Vol. 7, pp. 101-111.

Lončarić, D., Perisic Prodan, M. and Dlacic, J. (2018). "What makes summer vacation experience memorable? An empirical study from Croatia", Zbornik radova Veleučilišta u Rijeci/Journal of the Polytechnic of Rijeka, Vol. 6, No. 1, pp. 67-80.

Loureiro, S.M.C. (2014), "The role of the rural tourism experience economy in place attachment and behavioral intentions", International Journal of Hospitality Management, Vol. 40, No. 1, 1-9 DOI: https://doi.org/10.1016/j.ijhm.2014.02.010

Lundqvist, A., Liljander, V., Gummerus, J. and van Riel, A. (2013), "The impact of storytelling on the consumer brand experience: The case of a firm-originated story", Journal of Brand Management, Vol. 20, No. 4, pp. 283-297 https:/doi.org/10.1057/bm.2012.15

McBoyle, G. (1996), "Green tourism and Scottish distilleries”, Tourism Management, Vol. 17, No. 4., pp. 255 263 DOI: https://doi.org/10.1016/0261-5177(96)00017-9

Mitchell, M. A. and Orwig, R. A. (2002). "Consumer experience tourism and brand bonding", Journal of Product \& Brand Management, Vol. 11, No. 1, pp. 30-41. https://doi.org/10.1108/10610420210419531 
ToSEE - Tourism in Southern and Eastern Europe, Vol. 5, pp. 291-306, 2019

I. First Komen, S. Stamenić Oštrić: BRANDING TRADITIONAL AND NATURAL PRODUCTS BY ...

Mykletun, R.J. and Gyimothy, S. (2010), "Beyond the renaissance of the traditional Voss sheep's-head meal Tradition, culinary art, scariness and entrepreneurship", Tourism Management, Vol. 31, No. 3, pp 434-446.

Oliva, E. and Paliaga, M. (2012), "Research of Influence of Autochthonous Regional Products on Regional Brand- Example of The Istrian Region”, Ekonomska misao i praksa, Vol. 21, No. 1, pp. 363-379.

Pine, B.J.I.I. and Gilmore, J.H. (1998), "Welcome to the experience economy”, Harvard Business Review, Vol. 76, No. 4, 97-105.

Prince, S. (2017), "Working towards sincere encounters in volunteer tourism: an ethnographic examination of key management issues at a Nordic eco-village", Journal of Sustainable Tourism, Vol. 25, No. 11, 1617-1632.

Renton, M., Daellenbach, U., Davenport, S., and James, R.E. (2016), "Finding fit: An exploratory look at SME brand orientation and brand management in the New Zealand food and beverage sector", Journal of Brand Management, Vol. 23, No. 3, pp. 289-305.

Ryu. K., Lehto, X.Y., Gordon, S.E. and Fu, X. (2019), "Effect of a brand story structure on narrative transportation and perceived brand image of luxury hotels", Tourism Management, Vol. 71, pp. 348-363. DOI: 10.1016/j.tourman.2018.10.021

Schouteten, J.J., Gellynck, X., Slabbinck, H. (2019), "Influence of organic labels on consumer's flavor perception and emotional profiling: Comparison between a central location test and home-use-test", Food Research International, Vol. 116, pp. 1000-1009. DOI: 10.1016/j.foodres.2018.09.038

Sidali, K. L., Kastenholz, E. and Bianchi, R. (2015), "Food Tourism, Niche Markets and Products in Rura Tourism: Combining the Intimacy Model and the Experience Economy as a Rural Development Strategy", Journal of Sustainable Tourism, Vol. 23, No. 8-9, 1179-1197, DOI: $10.1080 / 09669582.2013 .836210$

Solana Nin (2018), viewed $20^{\text {th }}$ December 2018, http://www.solananin.hr/en/products/salt/

Solja, E., Liljander, V. and Soderlund, M. (2018), "Short brand stories on packaging: An examination of consumer responses", Psychology \& Marketing, Vol. 35, No. 4, pp. 294-306, DOI: $10.1002 /$ mar.21087

Taheri, B., Farrington, T., Curran, R. and O'Gorman, K. (2018), "Sustainability and the authentic experience. Harnessing brand heritage - a study from Japan", Journal of Sustainable Tourism, Vol. 26, No. 1, pp. 49-67.

Trip advisor (2019), viewed $18^{\text {th }}$ February 2019, https://www.tripadvisor.com/Attraction_Review-g303820d6556685-Reviews-Solana_Nin_Salt_Museum-Nin_Zadar_County_Dalmatia.html

TZ Nin (2019), viewed, $2^{\text {nd }}$ January 2019, www.nin.hr/en

TZ Zadar county (2019), viewed, $2^{\text {nd }}$ January 2019 www.zadar.hr/hr/

TZ Zadar (2019), viewed, $2^{\text {nd }}$ January 2019 https://www.zadar.travel/

Wiles, A. and Crawford, A. (2017), "Network hospitality in the share economy Understanding guest experiences and the impact of sharing on lodging", International Journal of Contemporary Hospitality Management, Vol. 29, No. 9, pp. 2444-2463.

Ivana First Komen, $\mathrm{PhD}$, Associate Professor

University of Rijeka, Faculty of Economics and Business

Ivana Filipovića 4, 51000 Rijeka, Croatia

Phone: +385 51355169

E-mail: ivana.first.komen@efri.hr

Sanja Stamenić Oštrić, PhD, Marketing Director

Solana Nin

Ilirska cesta 7, $23210 \mathrm{Nin}$, Croatia

Phone: +385 51355169

E-mail: sanja@ solananin.hr 